\title{
50. JURASSIC TO EOCENE PLATE TECTONIC RECONSTRUCTIONS IN THE KERGUELEN PLATEAU REGION ${ }^{1}$
}

\author{
Jean-Yves Royer ${ }^{2}$ and Millard F. Coffin ${ }^{3}$
}

\begin{abstract}
We present a series of preliminary reconstructions for the Kerguelen Plateau region from the Late Jurassic to the Eocene that summarize and review the outstanding questions about its plate tectonic evolution. The development of the Indian and adjacent Southern oceans began in Middle to Late Jurassic time with the breakup of Gondwana. Marine magnetic anomalies and limited Deep Sea Drilling Project and Ocean Drilling Program core samples have been used to date the oceanic crust. Fracture zone trends interpreted from satellite (SEASAT and GEOSAT) altimetry, and marine seismic, gravity, and magnetic data have been combined with crustal dates to produce kinematic models of the plates through time. Between the Jurassic and the Late Cretaceous, time controls on the plate tectonic evolution of the region are few. Mesozoic marine magnetic anomalies off the shore of East Africa, Antarctica, and Western Australia document plate motions during the interval; however, extensive areas of oceanic crust from which no anomalies have been identified, including that created during the Cretaceous Long Normal Polarity Interval, and a dearth of fracture zones prevent detailed links with the much better defined plate kinematic synthesis for the past $84 \mathrm{~m}$.y. The Kerguelen Plateau/Broken Ridge complex was emplaced at $\sim 110 \mathrm{Ma}$ in a region flanked by Greater India, Australia, and Antarctica. Between then and $\sim 43 \mathrm{Ma}$, when seafloor spreading between the Kerguelen Plateau and Broken Ridge began, our model includes transform motions between the northern and southern sectors of the Kerguelen Plateau.
\end{abstract}

\section{INTRODUCTION}

The plate kinematic history of the Indian and adjacent Southern oceans has been analyzed and described since shortly after the advent of the plate tectonics paradigm. Marine magnetic (McKenzie and Sclater, 1971; Norton and Sclater, 1979) and SEASAT/GEOSAT radar altimeter (Royer and Sandwell, 1989) data have been used to show that the oceans formed by a series of seafloor-spreading episodes and differing plate geometries (Figs. 1 and 2). Although the Cenozoic evolution of the ocean basins is fairly well known, the Mesozoic history is more problematic because of the Cretaceous Long Normal Polarity Interval and the scarcity of marine magnetic data from areas of suspected older crust. Our intent is to summarize the plate kinematic evolution of the ocean basins surrounding the Kerguelen Plateau/Broken Ridge complex and to outline the major questions about the tectonic evolution of this region between the Late Jurassic and the middle Eocene.

\section{RECONSTRUCTIONS}

Gondwana began to break up and disperse in Mesozoic time. In some cases, rifting preceded breakup by many tens of millions of years, and extensive volcanism and associated intrusions commonly accompanied the rifting (e.g., Hinz, 1981; Cox, 1988; Mahoney, 1988; Davies et al., 1989). Jurassic through Eocene seafloor spreading in the Indian Ocean region occurred in five major phases (Table 1). During the first, in Late Jurassic time, Gondwana rifted into two major lithospheric plates, East and West Gondwana. In the Indian Ocean sector, East Gondwana included Madagascar, the Seychelles, Greater India, Sri Lanka, Australia, and Antarctica; West

\footnotetext{
${ }^{1}$ Wise, S. W., Jr., Schlich, R., et al., 1992. Proc. ODP, Sci. Results, 120: College Station, TX (Ocean Drilling Program).

2 Laboratoire de Géodynamique sous-marine-O.O.V., B.P. 48, 06230 Villefranche sur mer, France.
}

Gondwana included Africa. In the second phase, in Early Cretaceous time, East and West Gondwana dispersed and reorganized through the transfer of crustal blocks. Madagascar/Seychelles/Greater India separated from Australia/Antarctica. Later on, relative motion between Africa and Madagascar/Seychelles/Greater India ceased. The third phase, starting in mid-Cretaceous time, was marked by a further disintegration and reorganization of the Gondwana fragments into four plates: Seychelles/Greater India and Africa/Madagascar broke up, as did Australia (including Broken Ridge and the Northern Kerguelen Plateau) and Antarctica (including the Southern Kerguelen Plateau). In the fourth phase, the Seychelles transferred from the Indian to the African plate in Paleocene time, and the number of plates remained at four. In the fifth phase, India and Australia joined to become one plate, leaving a total of three. At the same time, the northern sector of the Kerguelen Plateau was transferred from the Indo-Australian Plate to the Antarctic Plate as Broken Ridge and the Kerguelen Plateau were separated by the westward-propagating Southeast Indian Ridge in Eocene time.

In the following, we describe briefly these salient events (using the time scales of Berggren et al., 1985; Kent and Gradstein, 1985; Handschumacher et al., 1988) in the tectonic development of the southern Indian and adjacent Southern oceans. The 110-Ma and older reconstructions, based on published data, are considered qualitative and provisional, pending a thorough analysis of all pertinent geophysical and geological data. No satisfactory model has yet been proposed for the early opening of the Indian Ocean. Norton and Sclater's (1979) model was based on very sparse data. Ségoufin and Patriat (1980) focused on the relative motions of the African, Antarctic, and Madagascan plates. Bergh (1987) proposed different solutions for the Antarctic/Africa relative motions, whereas Powell et al. (1988) proposed a model limited to the Indian/Antarctic/Australian plate system. Incompatibilities among these different models highlight the necessity of considering all of the relevant plates simultaneously. Some of the ideas used in our model were developed by 


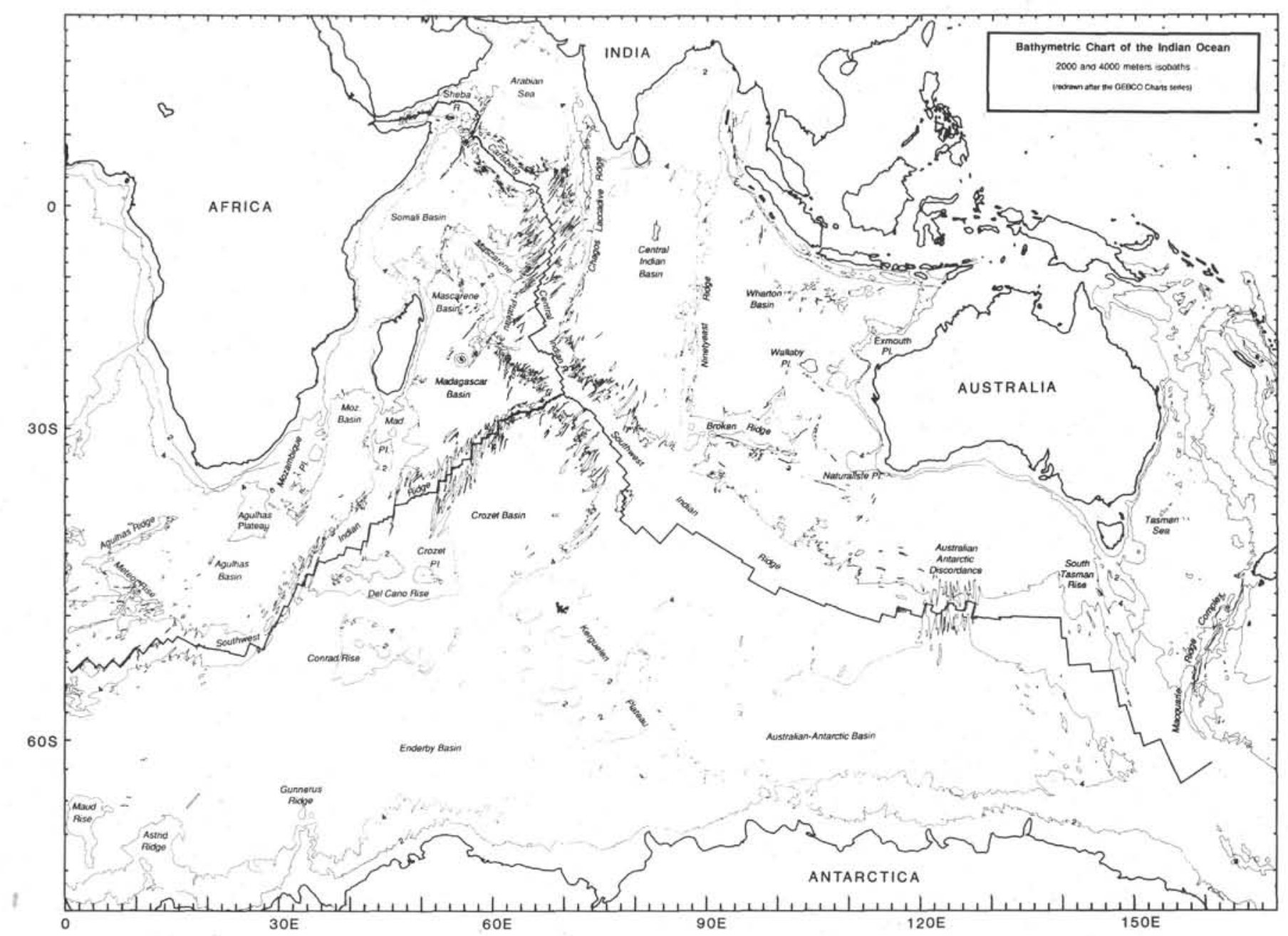

Figure 1. Bathymetric chart of the Indian Ocean (2000- and 4000-m isobaths) after Royer et al. (1989).

Lawver et al. (in press). We used the pre-breakup configuration for Gondwana of Lawver and Scotese (1987) as a starting point at $165 \mathrm{Ma}$. The relative position of Madagascar relative to Africa at $130 \mathrm{Ma}$ (M10) and $119 \mathrm{Ma}$ (M0) are based on Ségoufin and Patriat's (1980) model. The relative motions of Australia and Antarctica between 165 and $43 \mathrm{Ma}$ are from Royer and Sandwell (1989). For the pre-M0 reconstructions of Africa and Antarctica, we matched Mesozoic lineations in the Mozambique Channel with those off Dronning Maud Land in Antarctica. The rates and directions of spreading in the Perth Basin were used to constrain the India/Australia relative motions. Other geometrical constraints (e.g., no overlap between India and Madagascar) were also taken into account. The 84-Ma and younger reconstructions are based largely on the more quantitative plate kinematic analysis of Royer et al. (1988) and Royer and Sandwell (1989). We interpreted a transform boundary between the northern and southern provinces of the Kerguelen Plateau along the $77^{\circ} \mathrm{E}$ Graben (Coffin et al., in prep.). The rotation parameters determined in this study are provided in the figure captions.

\section{BREAKUP CONFIGURATION}

Although rifting, associated rift volcanism and intrusion, and probable continental extension occurred between East and West Gondwana before $200 \mathrm{Ma}$, at least as early as Permo-Carboniferous time (e.g., review in Coffin and Rabinowitz, 1988), no oceanic crust of Early Jurassic or greater age has been identified in the Indian or adjacent Southern oceans. In the region that was to become the Indian Ocean, the initial rifts separated West Gondwana, which included Africa, from East Gondwana, which included Madagascar, the Seychelles, Greater India, Australia, and Antarctica. East and West Gondwana may have undergone an episode of stretching at nearly right angles to the subsequent spreading direction (Coffin and Rabinowitz, 1987, 1988; Reeves et al., 1987). The pre-rift fit of Gondwana components is poorly constrained because of a scarcity of information on continental extension.

Continental extension and limited seafloor spreading (Fig. 3) began to occur between West and East Gondwana (Rabinowitz et al., 1983; Coffin and Rabinowitz, 1987), and between northwest Australia (East Gondwana) and its unidentified conjugate ("Argo" land mass of Powell et al., 1988). The overall plate configuration at the time of breakup is uncertain because of the poorly defined continent/ocean boundaries of the Gondwana fragments.

The age of the oldest oceanic crust in the southern Indian Ocean is not known. Larson (1975) estimated that oceanic crust began forming off northwest Australia at the time of magnetic lineation M25 (157 Ma) or earlier; with additional data Fullerton et al. (1989) identified lineation M26 (158 Ma). However, drilling on magnetic lineation M26 off northwest Australia provided a date of Early Cretaceous (Gradstein, Ludden, et al., 1990), or $\sim 20 \mathrm{~m}$.y. younger than the accepted 


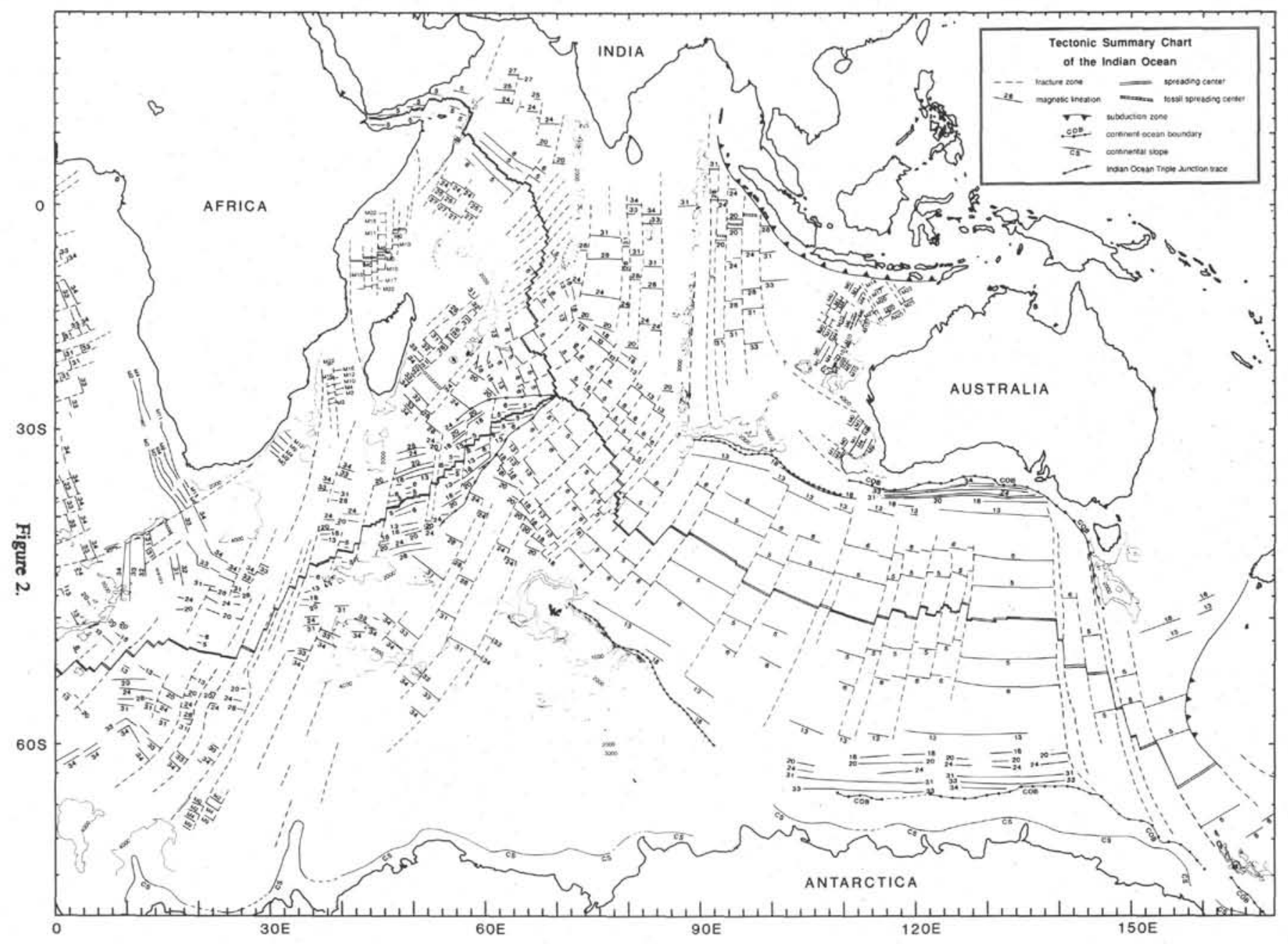

Figure 2. Tectonic fabric chart of the Indian Ocean (from Royer et al., 1989).

Table 1. Indian Ocean spreading chronology.

$165 \mathrm{Ma}$

M10/M0 - 132/119

$\mathrm{Ma}$

\begin{tabular}{|c|}
\hline Africa \\
\hline Madagascar \\
Seychelles \\
Greater India \\
Australia \\
Antarctica \\
\hline
\end{tabular}

$110 \mathrm{Ma}$

\begin{tabular}{|c|}
\hline Africa \\
Madagascat \\
\hline Seychelles \\
Greater India \\
\hline
\end{tabular}

\begin{tabular}{|c|}
\hline Australia \\
Broken Ridge \\
Kerguelen Plateau \\
Antarctica \\
\hline
\end{tabular}

Note: Rippled lines indicate uncertain plate configurations.
C34 - 84 Ma
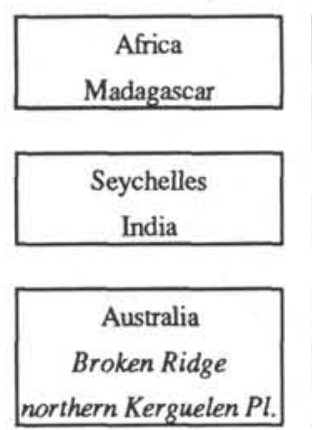

Antarctica

southern Kerguelen $P l$.
C28 - $64 \mathrm{Ma}$

C18 - $43 \mathrm{Ma}$

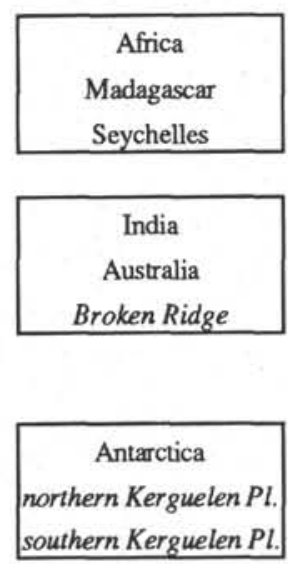




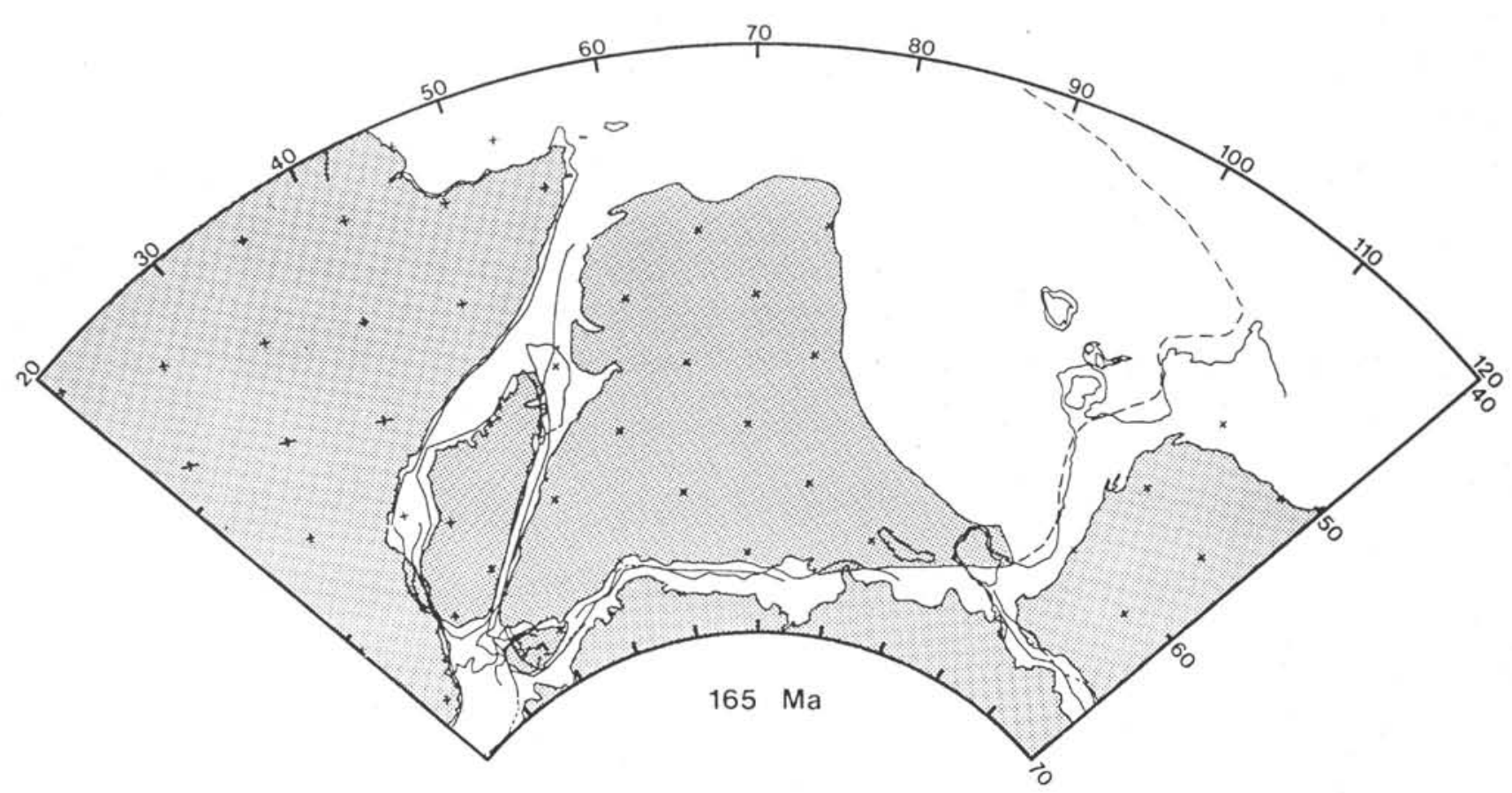

Figure 3. Plate tectonic reconstruction at $165 \mathrm{Ma}$. Seafloor spreading has begun between East and West Gondwana, and off northwest Australia. In this reconstruction and the following figures, Antarctica is held fixed in its present-day coordinates. Dashed line in this figure and in Figures 4, 5, and 6 indicates a possible northern boundary for Greater India. Rotation parameters: IND/ANT: $3.6^{\circ} \mathrm{S}, 15.3^{\circ} \mathrm{E}$, angle $=-92.01^{\circ}$; AFR/ANT: $15.1^{\circ} \mathrm{S}, 16.5^{\circ} \mathrm{W}$, angle $=-56.27^{\circ}$ (after Lawver and Scotese, 1987).

date for M26, suggestingthat either the anomaly is misidentified and/or that the Jurassic/Cretaceous magnetic time scale is in error.

A controversy also exists about the identification of the oldest magnetic lineations in the Somali Basin, between Africa and Madagascar. Ségoufin and Patriat (1980) identified Anomaly M21; Rabinowitz et al. (1983), M25; and Cochran (1988), M22. Coffin and Rabinowitz (1987) extrapolated spreading rates to the oceanic crust between M25 and the interpreted continent/ocean boundary off East Africa, and calculated that seafloor spreading began at $\sim 165 \mathrm{Ma}$ in the Western Somali Basin. The drill bit has not penetrated basement or any sediment close to it in the Western Somali Basin; confirmation of the age of the crust awaits integration of various marine magnetic data sets and direct sampling.

Seafloor spreading apparently propagated to the south from the Western Somali Basin into the Mozambique Channel; in the latter, the oldest identified magnetic anomaly is M22 (152 Ma; Ségoufin, 1978; Simpson et al., 1979). Conjugate magnetic anomalies, the oldest identified one being M16 ( $\sim 142 \mathrm{Ma})$, lie off the Antarctic coast (Bergh, 1977, 1987).

\section{Ma (M10)-Valanginian}

Seafloor spreading commenced between Greater India and Western Australia (Fig. 4; Markl, 1974, 1978; Larson et al., 1979; Fullerton et al., 1989) after an extended rift phase that began in Permian time (von Rad and Exon, 1982). The Bunbury basalts of Western Australia were erupted just before the onset of spreading (Playford et al., 1976; Davies et al., 1989). If Greater India behaved as a rigid plate, continental extension and possible seafloor spreading are required between Greater India and Antarctica. Geologic evidence from the rift basins of eastern India indicates that rifting began in Jurassic time (Sastri et al., 1973). No magnetic anomalies have been identified in the Enderby Basin between the Kerguelen Plateau and Antarctica that would date the separation; how- ever, magnetic anomalies of apparent seafloor-spreading origin, unidentified at present but presumably Mesozoic, exist in the basin (Mizukoshi et al., 1986; Lamont-Doherty Geological Observatory, unpubl. data; R. Schlich, pers. comm., 1989). Definitive dating of the initiation of seafloor spreading between Antarctica and Greater India requires further analysis of the existing data and most probably acquisition of new magnetic data in the basin. Farther to the east, rifting had commenced in Jurassic time between Australia and Antarctica (Veevers, 1984).

The timing of the cessation of seafloor spreading in the Western Somali Basin between Madagascar/Seychelles/ Greater India and Africa has been a matter of debate. Ségoufin and Patriat (1980) and Cochran (1988) interpreted M0 (119 Ma) as the youngest anomaly in the basin, whereas Rabinowitz et al. (1983) and Coffin and Rabinowitz (1987) interpreted the youngest anomaly as M10 (132 Ma). The data do not preclude either of the interpretations. The latter would result in a simpler kinematic model, since seafloor spreading would have ceased in the Western Somali Basin when spreading began between Australia/Antarctica and Greater India (e.g., in the Perth Basin, Fig. 4). However, as pointed out by Lawver et al. (1985), a reconstruction with Madagascar in its present-day position relative to Africa as early as Chron M10 shows overlap with the Antarctic Plate, the position of which is derived from the Mesozoic anomalies in the Mozambique Channel and off Dronning Maud Land in Antarctica. This geometric constraint favors the former interpretation, and 119 Ma might also be when the spreading system between India/ Sri Lanka and Antarctica connected with the spreading ridge in the Mozambique Basin.

\section{Ma (M0)-Aptian}

Spreading had stopped in the Somali Basin between Madagascar/Seychelles/Greater India and Africa (see above; Ségoufin and Patriat, 1980; Rabinowitz et al., 1983; Cochran, 


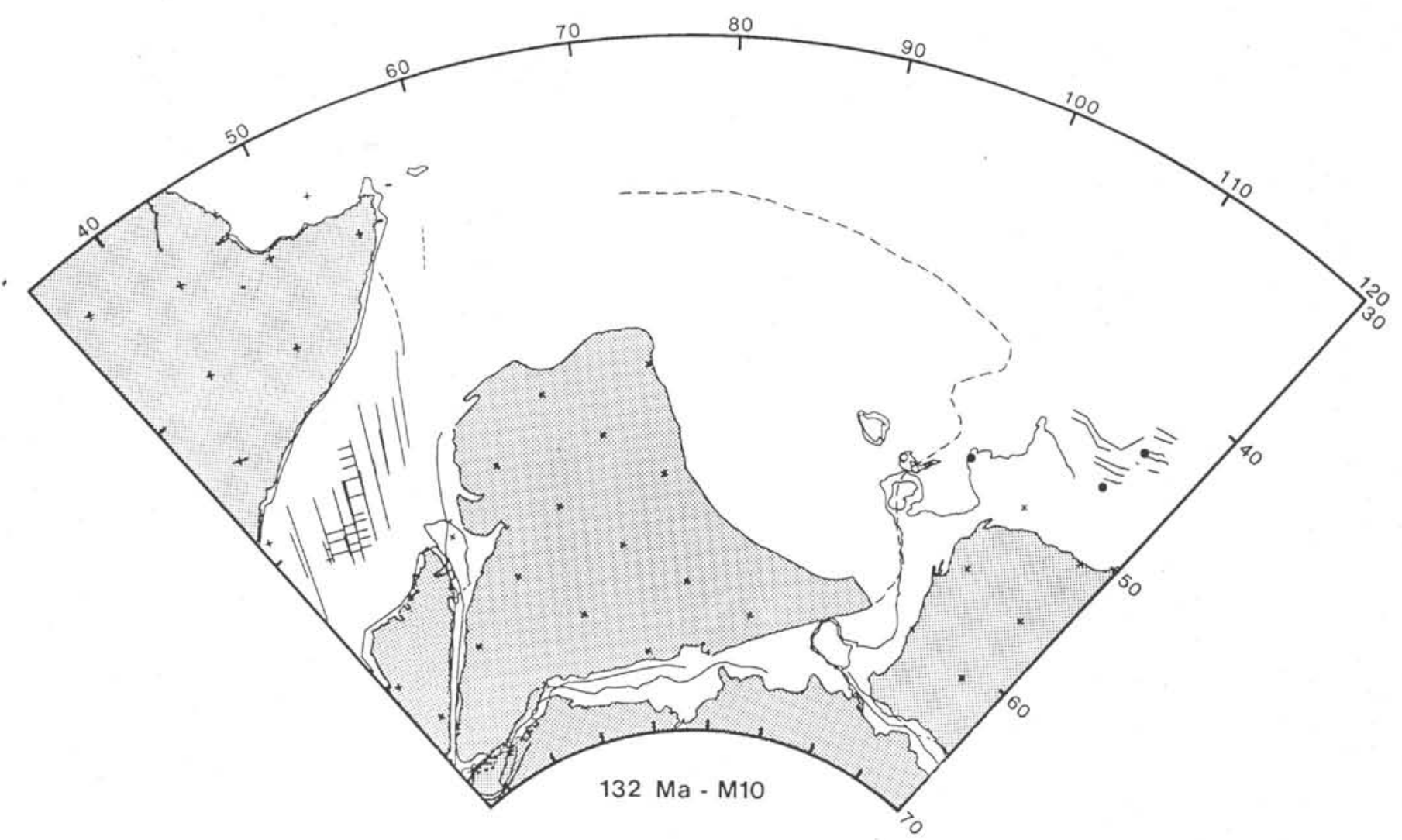

Figure 4. Plate tectonic reconstruction at $132 \mathrm{Ma}$ (M10). Madagascar/Seychelles/Greater India and Australia/Antarctica have begun to separate. Deep Sea Drilling Project (DSDP) and Ocean Drilling Program (ODP) sites are indicated by closed dots (in subsequent figures as well). Rotation parameters: IND/ANT: $2.0^{\circ} \mathrm{S}, 28.1^{\circ} \mathrm{E}$, angle $=-88.98^{\circ} ;$ AFR/ANT: $7.2^{\circ} \mathrm{S}, 27.9^{\circ} \mathrm{W}$, angle $=-47.71^{\circ}$.

1988). Spreading continued in the Mozambique Channel (Fig. 5; Ségoufin, 1978; Simpson et al., 1979), in the AfricanAntarctic Basin (Bergh, 1977, 1987), and off Western Australia (Markl, 1974, 1978; Larson, 1975, 1977; Larson et al., 1979) between Australia/Antarctica and Africa/Madagascar/Seychelles/Greater India. Rifting continued between Australia and Antarctica (Falvey and Mutter, 1981; Veevers, 1984).

\section{Ma-Albian}

The emplacement of the Kerguelen Plateau/Broken Ridge complex was nearly complete (Fig. 6; Leclaire et al., 1987; Whitechurch et al., this volume), and seafloor spreading is assumed to have been continuous during the Cretaceous Long Normal Polarity Interval, separating Australia/Antarctica and Africa/Madagascar/Seychelles/Greater India. Given the amount of crust generated between $132 \mathrm{Ma} \mathrm{(M10)}$ and $119 \mathrm{Ma}$ (M0) in the Perth Basin, and the distance from the Kerguelen Plateau (about $115 \mathrm{Ma}$ old) to the Antarctic margin, the breakup between India and Antarctica is probably not much older than the breakup between Greater India and Australia (recorded in the Perth Basin), unless seafloor spreading took place between the southern Kerguelen Plateau and Antarctica. The latter does not appear likely due to the presumed Mesozoic magnetic lineations in the Enderby Basin, as previously noted.

The location of the first crustal expression of the hotspot responsible for the formation of the Kerguelen/Broken Ridge complex is not yet clear. The Rajmahal Traps in northeastern India have been dated at $115 \mathrm{Ma}$ and interpreted as the first manifestation of the Kerguelen hotspot (Duncan, 1978; Curray et al., 1982; Mahoney et al., 1983; Davies et al., 1989). The source of the Naturaliste Plateau as well as the Bunbury basalts of southwest Australia, which have ages that range from 136 to $105 \mathrm{Ma}$ (Playford et al., 1976), may also have been the Kerguelen hotspot (Leclaire et al., 1987; Davies et al., 1989). The Prince Charles Mountains of onshore Antarctica have also been related to the hotspot (Storey et al., 1989). As illustrated in Figure 6, the dimensions of the entire volcanic province attributed to the Kerguelen hotspot is of the same order, that is, a few thousand $\mathrm{km}$ in diameter, as that proposed by White and McKenzie (1989) for the North Atlantic Tertiary volcanic province. No ridge, however, links the Naturaliste Plateau to Broken Ridge, and no direct link has yet been identified between the Rajmahal Trap and the Ninetyeast Ridge (e.g., Curray et al., 1982), as would be expected from the then extremely productive Kerguelen hotspot.

\section{Ma (C34)-Santonian}

Oceanic crust began to form between Africa/Madagascar and Greater India/Seychelles in the Mascarene Basin (Schlich, 1982); the linearity of the eastern Madagascan margin suggests that transform motion between the Indian and Madagascan plates may have occurred before $84 \mathrm{Ma}$ (Fig. 7). Practically nothing is known of the rift history between the two plates, which should be recorded on eastern Madagascar, the Seychelles, the northern part of the Maldive-Laccadive Ridge, the Laxmi Ridge, and western India. On the east coast of Madagascar, rift volcanics have been dated as Turonian and Santonian (Boast and Nairn, 1982). No Mesozoic rocks are known in the Seychelles archipelago (Baker, 1963), nor from the 


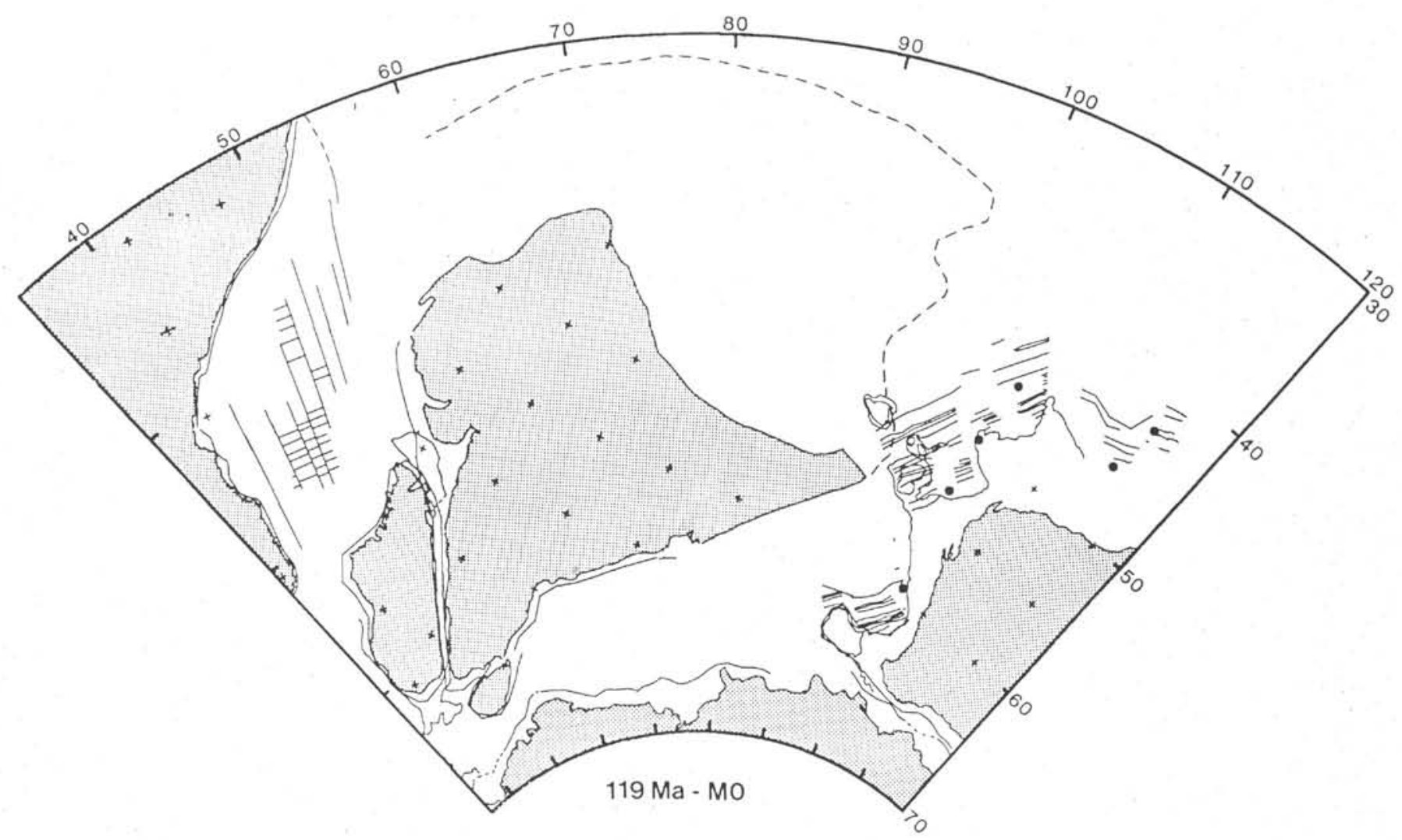

Figure 5. Plate tectonic reconstruction at $119 \mathrm{Ma}(\mathrm{M} 0)$ just before the emplacement of the Kerguelen Plateau/Broken Ridge complex. Seafloor spreading is about to stop between Africa and Madagascar as the Africa/Antarctica and India/Antarctica spreading systems are being connected. Rotation parameters: IND/ANT: $0.8^{\circ} \mathrm{S}, 9.7^{\circ} \mathrm{E}$, angle $=-81.97^{\circ}$; AFR/ANT: $7.0^{\circ} \mathrm{S}, 30.6^{\circ} \mathrm{W}$, angle $=-38.36^{\circ}$.

Laccadive-Maldive or Laxmi ridges (Whitmarsh, Weser, Ross, et al., 1974; Naini and Talwani, 1982; Backman, Duncan, et al., 1988). The basins along the western Indian coast have a minimum age of Jurassic and may possibly extend back to Permian time (Sahni, 1982).

Continental extension and possible limited seafloor spreading at rates of very few $\mathrm{mm} / \mathrm{yr}$ was occurring between Australia and Antarctica (Falvey and Mutter, 1981; Cande and Mutter, 1982; Veevers, 1984), and transform motion continued between the northern and southern sectors of the Kerguelen Plateau. Marine magnetic, with supplementary gravity and seismic, data have been used to support dates for the initiation of seafloor spreading between Australia and Antarctica at $52 \mathrm{Ma}$ (Weissel and Hayes, 1972), $90 \mathrm{Ma}$ (Cande and Mutter, 1982), and $95 \pm 5$ Ma (Veevers, 1986). Subsidence data contradict the former date (Mutter et al., 1985), and the recent acquisition of MCS data across the previously identified continent/ocean boundary (COB) and the oldest marine magnetic anomaly south of Australia cast doubt on the latter two dates (Willcox et al., 1988; Willcox, pers. comm.). These data show rotated fault blocks overlain by interpreted Early Cretaceous sediment extending seaward of the previously identified COB and oldest magnetic anomaly. Definition of the COB south of Australia, and dating of the initiation of seafloor spreading between Australia and Antarctica, await collection of high-quality MCS and ocean drilling data, respectively.

\section{Ma (C28)-Early Paleocene to 56 Ma (C24)-Early Eocene}

Seafloor spreading continued at a slow rate between Australia and Antarctica (Cande and Mutter, 1982; Mutter and
Cande, 1983), and transform motion continued between the northern and southern Kerguelen Plateaus (Figs. 8 and 9). Dates from the Ninetyeast Ridge drilling sites and the kinematic studies of the Central Indian, Crozet, Wharton, and Australian-Antarctic basins strongly constrain the path of the Kerguelen hotspot during the Cenozoic (Royer et al., 1991). During this time, the Kerguelen hotspot generated the northeastern part of the Kerguelen Plateau and the Ninetyeast Ridge.

\section{Ma (C18)-Middle Eocene}

Seafloor spreading accelerated to rates of $22 \mathrm{~mm} / \mathrm{yr}$ between Australia and Antarctica at C19 (44 Ma; Cande and Mutter, 1982; Mutter and Cande, 1983), and oceanic crust began to be created between the Kerguelen Plateau and Broken Ridge (Fig. 10; Houtz et al., 1977; Mutter and Cande, 1983; Munschy et al., this volume). Transform motion had ended between the Northern and Southern Kerguelen plateaus, as both sectors became part of the Antarctic plate. Relative motion between India and Australia had ceased in the Wharton Basin (Liu et al., 1983).

\section{MAJOR REMAINING QUESTIONS}

In synthesizing the Mesozoic and early Cenozoic plate tectonic history of the region surrounding the Kerguelen Plateau, we have attempted to point out areas of ignorance and of controversy. Some major questions that remain are (in rough chronological order):

1. What was the pre-rift configuration of Gondwana? 


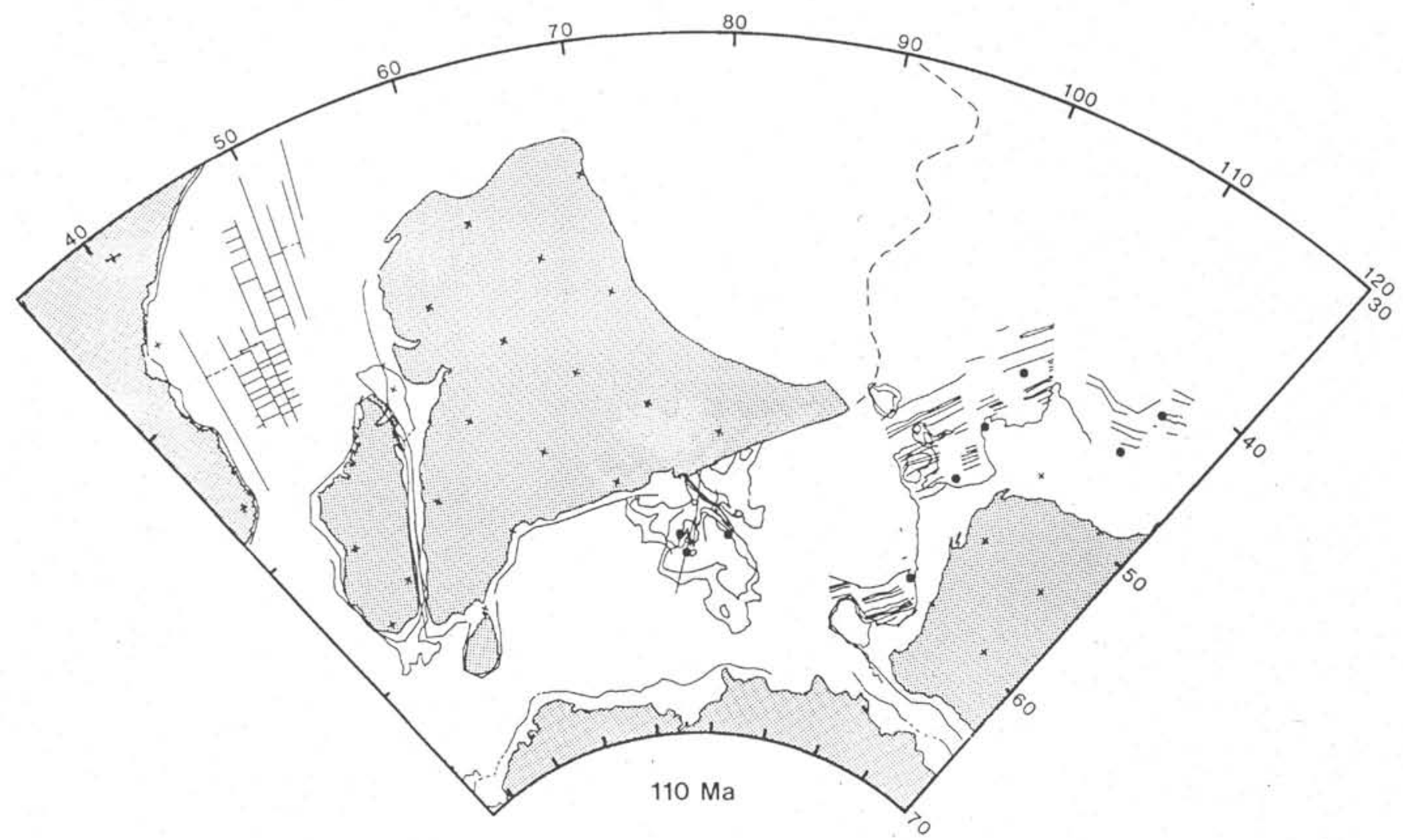

Figure 6. Plate tectonic reconstruction at $110 \mathrm{Ma}$ at the end of the major constructional phase of the Kerguelen Plateau/Broken Ridge complex. Relative motion continues between two plates: Africa/Madagascar/Seychelles/Greater India and Australia/Antarctica. Strike-slip motion has begun between the northern and southern sectors of the Kerguelen Plateau. Piston core and dredge sites are shown by asterisks. Rotation parameters: IND/ANT: $2.6^{\circ} \mathrm{S}, 10.3^{\circ} \mathrm{E}$, angle $=-78.64^{\circ}$; AFR/ANT: $6.3^{\circ} \mathrm{S}, 31.8^{\circ} \mathrm{W}$, angle $=-33.16^{\circ}$.

2. What was the configuration of Gondwana at the time of initial breakup?

3. What was the precise time of breakup between East and West Gondwana?

4. What landmass separated from northwest Australia, and at what time?

5. When was the first crustal expression of the Kerguelen hotspot, and how did it move through time (cf. Duncan, 1978; Mahoney et al., 1983; Davies et al., 1989; Storey et al., 1989)?

6. When and why did seafloor spreading cease in the Western Somali Basin?

7. When did seafloor spreading start and finish in the Enderby Basin?

8. When did seafloor spreading begin between Australia and Antarctica, and how did this spreading propagate to the west? Is there any history of transform motion on the Kerguelen Plateau?

9. Did transform motion occur between Madagascar and Greater India before the creation of oceanic crust in the Mascarene Basin? If so, when? Is there a relationship between Deccan volcanism and the breakup of Madagascar and India?

\section{ACKNOWLEDGMENTS}

We thank the Centre Nationale pour la Recherche Scientifique (CNRS), National Science Foundation (NSF), the Bureau of Mineral Resources (Australia), the Terres Australes et Antarctiques Françaises, and the Ocean Drilling Program for the opportunities to participate in geoscientific expeditions in the southern Indian and adjacent Southern oceans. This work has been supported by the CNRS, NSF Grant No. OCE 86-17193, and the sponsors of the Paleoceanographic Mapping Project at the Institute for Geophysics, University of Texas at Austin (UTIG). We appreciate critical reviews by Steve Cande and Dave Rowley. This is UTIG Contribution No. 823 and Laboratoire de.Géodynamique sous-marine Contribution No. 545 .

\section{REFERENCES}

Backman, J., Duncan, R. A., et al., 1988. Proc. ODP, Init. Repts., 115: College Station, TX (Ocean Drilling Program).

Baker, B. H., 1963. Geology and mineral resources of the Seychelles archipelago. Mem. Geol. Surv. Kenya, No. 3.

Berggren, W. A., Kent, D. V., Flynn, J. J., and Van Couvering, J. A., 1985. Cenozoic geochronology. Geol. Soc. Am. Bull., 96:1407-1418.

Bergh, H. W., 1977. Mesozoic seafloor off Dronning Maud Land, Antarctica. Nature, 269:686-687.

1987. Underlying fracture zone nature of Astrid Ridge off Antarctica's Queen Maud Lane. J. Geophys. Res., 92:475-484.

Boast, J., and Nairn, A.E.M., 1982. An outline of the geology of Madagascar. In Nairn, A.E.M., and Stehli, F. G. (Eds.), The Ocean Basins and Margins (Vol. 6): New York (Plenum), 649-696.

Cande, S. C., and Mutter, J. C., 1982. A revised identification of the oldest sea-floor spreading anomalies between Australia and Antarctica. Earth Planet. Sci. Lett., 58:151-160.

Cochran, J. R., 1988. Somali Basin, Chain Ridge, and origin of the Northern Somali Basin gravity and geoid low. J. Geophys. Res., 93:11985-12008.

Coffin, M. F., and Rabinowitz, P. D., 1987. Reconstruction of Madagascar and Africa: evidence from the Davies Fracture Zone and Western Somali Basin. J. Geophys. Res., 92:9385-9406. 
1988. Evolution of the East African continental margin and the Western Somali Basin. Spec. Pap. Geol. Soc. Am., No. 226. Cox, K. G., 1988. The Karoo Province. In Macdougall, J. D. (Ed.), Continental Flood Basalts: Dordrecht (Kluwer), 239-271.

Curray, J. R., Emmel, F. J., Moore, D. G., and Raitt, R. W., 1982. Structure, tectonics and geological history of the northeastern Indian Ocean. In Nairn, A.E.M., and Stehli, F. G. (Eds.), The Ocean Basins and Margins (Vol. 6): New York (Plenum), 399-450.

Davies, H. L., Sun, S.-S., Frey, F. A., Gautier, I., McCulloch, M. T., Price, R. C., Bassias, Y., Klootwijk, C. T., and Leclaire, L., 1989. Basalt basement from the Kerguelen Plateau and the trail of the DUPAL plume. Contrib. Mineral. Petrol., 103:457-469.

Duncan, R. A., 1978. Geochronology of basalts from the Ninetyeast Ridge and continental dispersion in the eastern Indian Ocean, $J$. Volcanol. Geotherm. Res., 4:283-405.

Falvey, D. A., and Mutter, J. C., 1981. Regional plate tectonics and the evolution of Australia's passive continental margins. BMR J. Aust. Geol. Geophys., 6:1-29.

Fullerton, L. G., Sager, W. W., and Handschumacher, D. W., 1989. Late Jurassic-Early Cretaceous evolution of the eastern Indian Ocean adjacent to northwest Australia. J. Geophys. Res., 94:29372953.

Gradstein, F. M., Ludden, J. N., et al., 1990. Proc. ODP, Init. Repts., 123: College Station, TX (Ocean Drilling Program).

Handschumacher, D. W., Sager, W. W., Hilde, T.W.C., and Bracey, D. R., 1988. Pre-Cretaceous tectonic evolution of the Pacific plate and extension of the geomagnetic polarity reversal time scale with implications for the origin of the Jurassic "Quiet Zone." Tectonophysics, 155:365-380.

Hinz, K., 1981. A hypothesis on terrestrial catastrophes: wedges of very thick oceanward dipping layers beneath passive margins: their origin and paleoenvironmental significance. Geol. Jahrb., E22:3-28.

Houtz, R. E., Hayes, D. E., and Markl, R. G., 1977. Kerguelen Plateau bathymetry, sediment distribution and crustal structure. Mar. Geol., 25:95-130.

Kent, D. V., and Gradstein, F. M., 1985. A Cretaceous and Jurassic geochronology. Geol. Soc. Am. Bull., 96:1419-1427.

Larson, R. L., 1975. Late Jurassic seafloor spreading in the eastern Indian Ocean. Geology, 3:69-71.

1977. Early Cretaceous breakup of Gondwanaland off western Australia. Geology, 5:57-60.

Larson, R. L., Mutter, J. C., Diebold, J. B., Carpenter, G. B., and Symonds, P. A., 1979. Cuvier Basin: a product of ocean crust formation by Early Cretaceous rifting off western Australia. Earth Planet. Sci. Lett., 45:105-114.

Lawver, L. A., Sclater, J. G., and Meinke, L., 1985. Mesozoic and Cenozoic reconstructions of the South Atlantic. Tectonophysics, 114:233-254.

Lawver, L. A., Royer, J.-Y., and Sandwell, D. T., in press. Evolution of the Antarctic continental margins. In Thomson, M.R.A. (Ed.), Proc. 5th Int. Antarct. Earth Sci. Symp., 1987.

Lawver, L. A., and Scotese, C. R., 1987. A revised reconstruction of Gondwanaland. In McKenzie, G. D. (Ed.), Gondwana Six: Structure, Tectonics, and Geophysics. Am. Geophys. Union Geophys. Monogr. Ser., 40:17-23.

LeClaire, L., Bassias, Y., Denis-Clochiatti, M., Davies, H. L., Gautier, I., Gensous, B., Giannesini, P.-J., Patriat, P., Ségoufin, J., Tesson, M., and Wannesson, J., 1987. Lower Cretaceous basalt and sediments from the Kerguelen Plateau. Geo-Mar. Lett., 7:169-176.

Liu, C.-S., Curray, J. R., and McDonald, J. M., 1983. New constraints on the tectonic evolution of the eastern Indian Ocean. Earth Planet. Sci. Lett., 65:331-342.

Mahoney, J. J., 1988. Deccan Traps. In Macdougall, J. D. (Ed.), Continental Flood Basalts: Dordrecht (Kluwer Acad. Publ.), 151-194.

Mahoney, J. J., Macdougall, J. D., Lugmair, G. W., and Gopalan, K., 1983. Kerguelen hotspot source for Rajmahal Traps and Ninetyeast Ridge? Nature, 303:385-389.

Markl, R. G., 1974. Evidence for the breakup of eastern Gondwanaland by the Early Cretaceous. Nature, 251:196-200.

, 1978. Further evidence for the Early Cretaceous breakup of Gondwanaland off southwestern Australia. Mar. Geol., 26:41-48.
McKenzie, D. P., and Sclater, J. G., 1971. The evolution of the Indian Ocean since the Late Cretaceous. Geophys. J. R. Astron. Soc., 25:437-528.

Mizukoshi, I., Sunouchi, H., Saki, T., Sato, S., and Tanahashi, M., 1988. Preliminary report of geological geophysical surveys off Amery Ice Shelf, East Antarctica. Mem. Nat. Inst. Polar Res. Spec. Iss. Jpn., 43:48-61.

Mutter, J. C., and Cande, S. C., 1983. The early opening between Broken Ridge and Kerguelen Plateau. Earth Planet. Sci. Lett., 65:369-376.

Mutter, J. C., Hegarty, K. A., Cande, S. C., and Weissel, J. K., 1985. Breakup between Australia and Antarctica: a brief review in the light of new data. Tectonophysics, 114:255-279.

Naini, B. R., and Talwani, M., 1982. Structural framework and the evolutionary history of the continental margin of Western India. In Watkins, J. S., and Drake, C. L. (Eds.), Studies in Continental Margin Geology. AAPG, 167-191.

Norton, I. O., and Sclater, J. G., 1979. A model for the evolution of the Indian Ocean and the breakup of Gondwanaland. J. Geophys. Res., 84:6803-6830.

Playford, P. E., Cockbain, A. E., and Low, G. H., 1976. Geology of the Perth Basin, Western Australia. Bull.-Geol. Surv. West. Aust., 124:1-311.

Powell, C. McA., Roots, S. R., and Veevers, J. J., 1988. Pre-breakup continental extension in East Gondwanaland and the early opening of the eastern Indian Ocean. Tectonophysics, 155:261-283.

Rabinowitz, P. D., Coffin, M. F., and Falvey, D. A., 1983. The separation of Madagascar and Africa. Science, 220:67-69.

Reeves, C. V., Karanja, F. M., and MacLeod, I. N., 1987. Geophysical evidence for a failed Jurassic rift and triple junction in Kenya. Earth Planet. Sci. Lett., 81:299-311.

Royer, J.-Y., Patriat, P., Bergh, H., and Scotese, C. R., 1988. Evolution of the Southwest Indian Ridge from the Late Cretaceous (anomaly 34) to the middle Eocene (anomaly 20). Tectonophysics, 155:235-260.

Royer, J.-Y., Peirce, J. W., and Weissel, J. K., 1991. Tectonic constraints on hotspot formation of the Ninetyeast Ridge. In Peirce, J., Weissel, J., et al., Proc. ODP, Sci. Results, 121: College Station, TX (Ocean Drilling Program).

Royer, J.-Y., and Sandwell, D. T., 1989. Evolution of the eastern Indian Ocean since the Late Cretaceous: constraints from GEOSAT altimetry. J. Geophys. Res., 94:13755-13782.

Royer, J.-Y., Sclater, J. G., and Sandwell, D. T., 1989. A preliminary tectonic chart of the Indian Ocean. Proc. Indian Acad. Sci. Earth Planet. Sci., 98:7-24.

Sahni, A., 1982. The structure, sedimentation, and evolution of Indian continental margins. In Nairn, A.E.M., and Stehli, F. G. (Eds.), The Ocean Basins and Margins (Vol. 6): New York (Plenum), 353-398.

Sastri, V. V., Sinha, R. N., Gurcharan Singh, and Murti, K.V.S., 1973. Stratigraphy and tectonics of sedimentary basins on east coast of Peninsular India. AAPG Bull., 57:655-678.

Schlich, R., 1982. The Indian Ocean: aseismic ridges, spreading centers, and oceanic basins. In Nairn, A.E.M., and Stehli, F. G. (Eds.), The Ocean Basins and Margins (Vol. 6): New York (Plenum), 51-147.

Ségoufin, J., 1978. Anomalies magnétiques mésozoiques dans le bassin de Mozambique. C. R. Acad. Sci. Ser. 3, 287:109-112.

Ségoufin, J., and Patriat, P., 1980. Existence d'anomalies mésozoiques dans la basin de Somalie: implications pour les relations Afrique-Antarctique-Madagascar. C. R. Acad. Sci. Ser. 2, 291:8588.

Simpson, E.S.W., Sclater, J. G., Parsons, B., Norton, I., and Meinke, L., 1979. Mesozoic magnetic lineations in the Mozambique Basin. Earth Planet. Sci. Lett., 43:260-264.

Storey, M., Saunders, A. D., Tarney, J., Gibson, I. L., Norry, M. J., Thirlwall, M. F., Leat, P., Thompson, R. N., and Menzies, M. A., 1989. Contamination of Indian Ocean asthenosphere by the Kerguelen-Heard mantle plume. Nature, 338:574-576.

Veevers, J. J. (Ed.), 1984. Phanerozoic Earth History of Australia: Oxford (Clarendon Press). 
1986. Breakup of Australia and Antarctica estimated as mid-Cretaceous $(95 \pm 5 \mathrm{Ma})$ from magnetic and seismic data at the continental margin. Earth Planet. Sci. Lett., 77:91-99.

von Rad, U., and Exon, N. F., 1982. Mesozoic-Cenozoic sedimentary and volcanic evolution of the starved passive continental margin off northwest Australia. In Watkins, J. S., and Drake, C. L. (Eds.), Studies in Continental Margin Geology: AAPG Mem., 34:253-281.

Weissel, J. K., and Hayes, D. E., 1972. Magnetic anomalies in the southeast Indian Ocean. In Hayes, D. E. (Ed.), Antarctic Oceanology (Vol. 2): Am. Geophys. Union Antarct. Res. Ser., 19:165-196.

White, R. S., and McKenzie, D. P., 1989. Magmatism at rift zones: the generation of volcanic continental margins and flood basalts. $J$. Geophys. Res., 94:7685-7729.
Whitmarsh, R. B., Weser, O. E., Ross, D. A., et al., 1974. Init. Repts. DSDP, 23: Washington (U.S. Govt. Printing Office).

Willcox, J. B., Stagg, H.M.J., Davies, H. L., et al., 1988. Rig Seismic research cruises 10 \& 11: geology of the Central Great Australian Bight region. Rep. Bur. Mineral Resour. Geol. Geophys. Aust., No. 286.

Date of initial receipt: 3 August 1990

Date of acceptance: 11 March 1991

Ms 120B-200

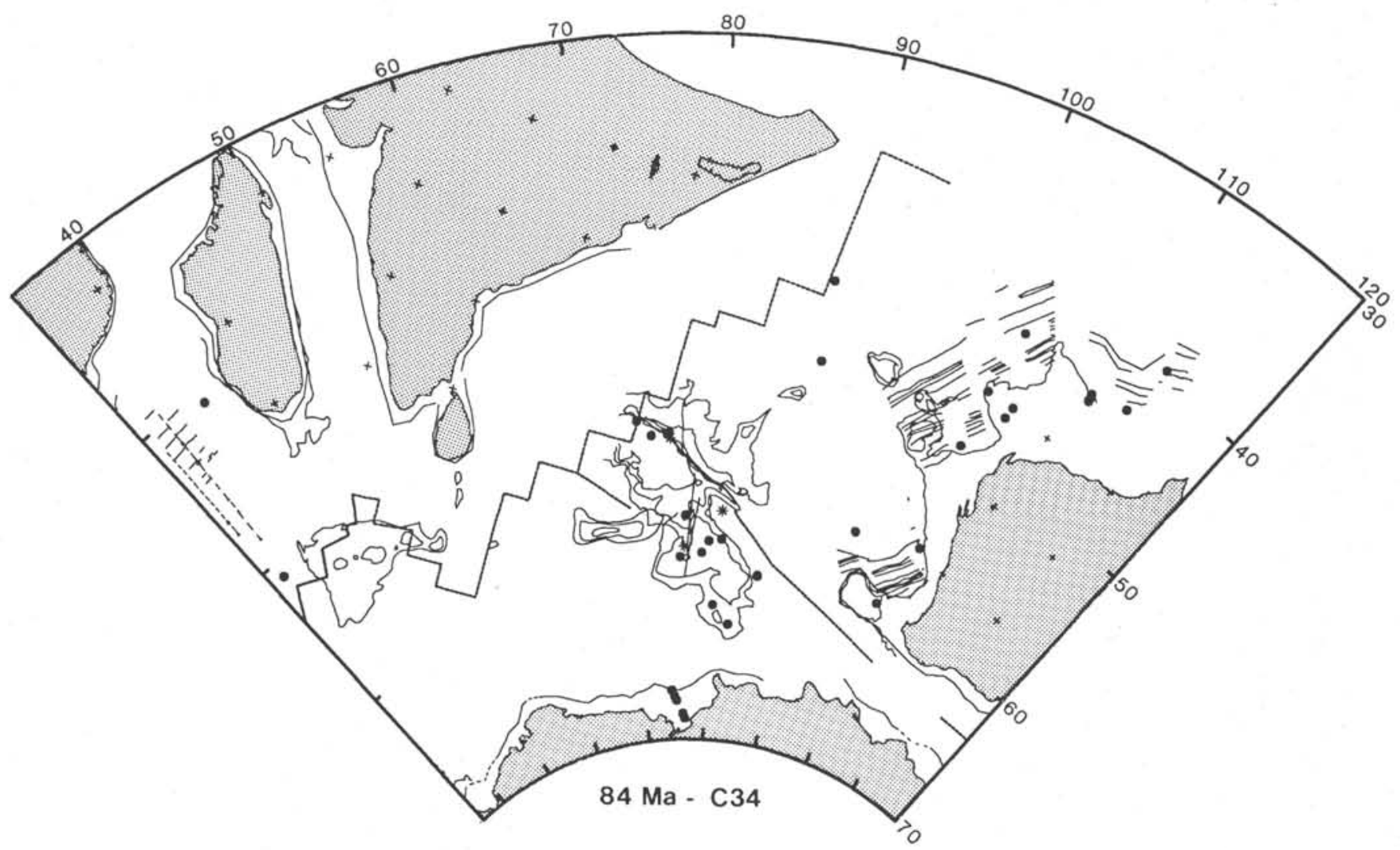

Figure 7. Plate tectonic reconstruction at $84 \mathrm{Ma}$ (C34). After a major plate boundary reorganization that probably occurred in the mid-Cretaceous, the two plates of Figure 6 have broken into four plates: Africa/Madagascar, Greater India/Seychelles, Africa/Madagascar, Australia, and Antarctica. Strike-slip motion continues between the northern and southern sectors of the Kerguelen Plateau. The bolder staircase-shaped line shows the location of active spreading ridges. The configuration of the spreading centers in the Mascarene Basin is poorly documented. Reconstruction after Royer and Sandwell (1989) and Royer et al. (1988). 


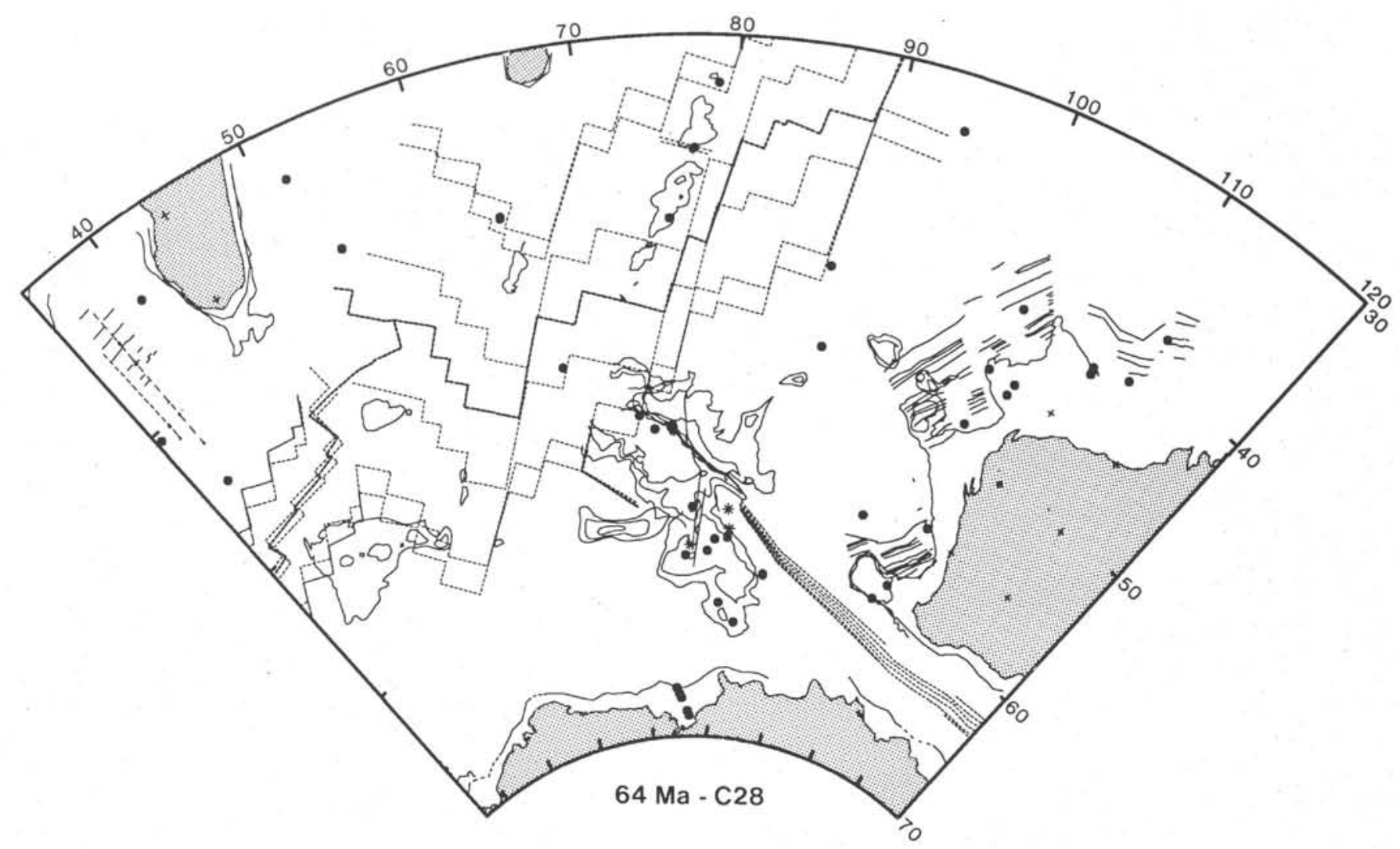

Figure 8. Plate tectonic reconstruction at $64 \mathrm{Ma}(\mathrm{C} 28)$. Slow seafloor spreading continues between Australia and Antarctica. It is not yet clear how and where the Australian/Antarctic spreading ridge connected with the Indian/Australian and Indian/Antarctic spreading ridges. Older isochron lines are shown by dashed lines. Reconstruction after Royer and Sandwell (1989) and Royer et al. (1988). 


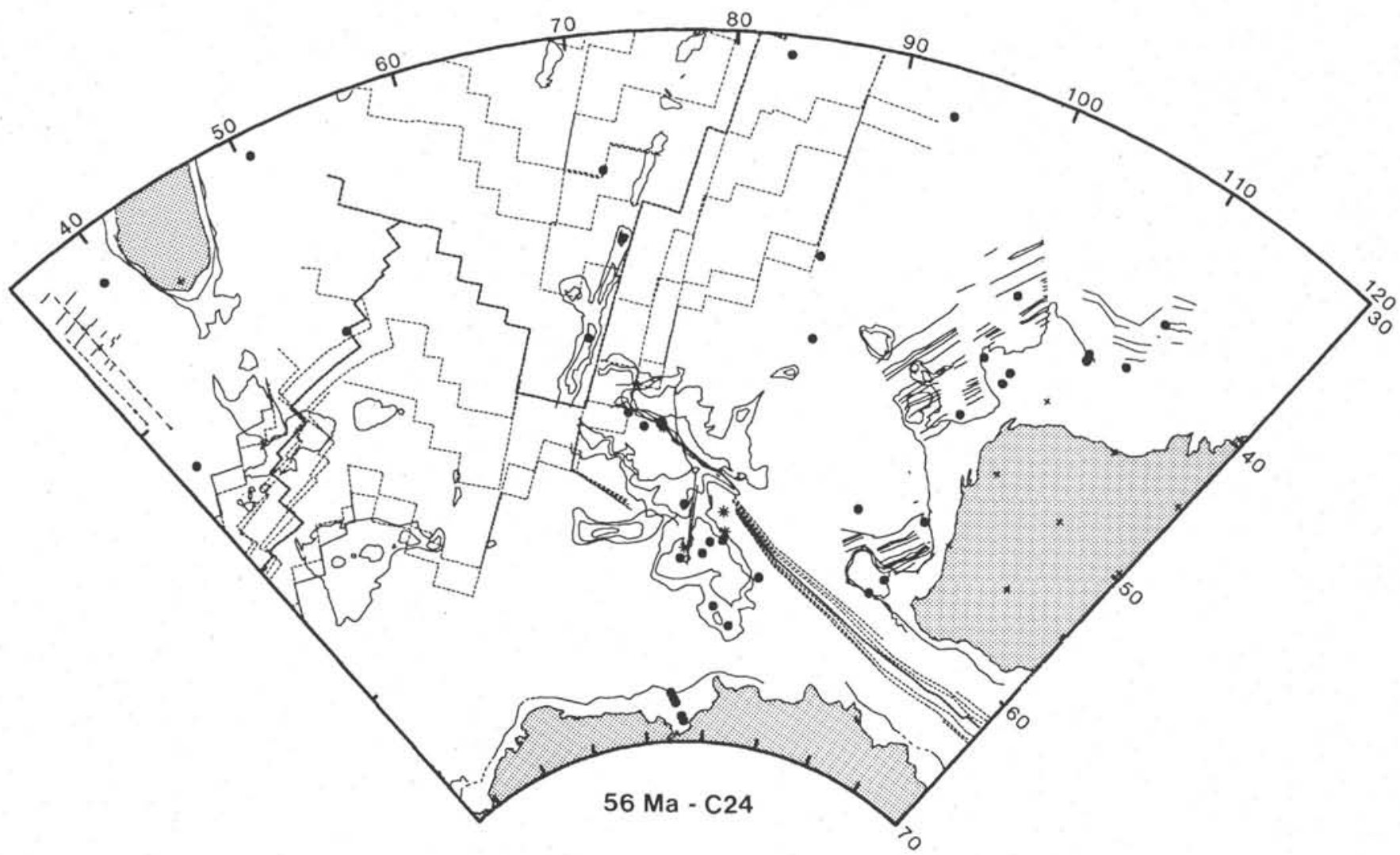

Figure 9. Plate tectonic reconstruction at $56 \mathrm{Ma}$ (C24). Slow seafloor spreading continues between Australia and Antarctica, and transform motion continues between the northern and southern Kerguelen Plateau sectors. The Ninetyeast Ridge and the northeastern part of the Kerguelen Plateau are being constructed over the Kerguelen hotspot (Royer et al., 1991). Reconstruction after Royer and Sandwell (1989) and Royer et al. (1988). 


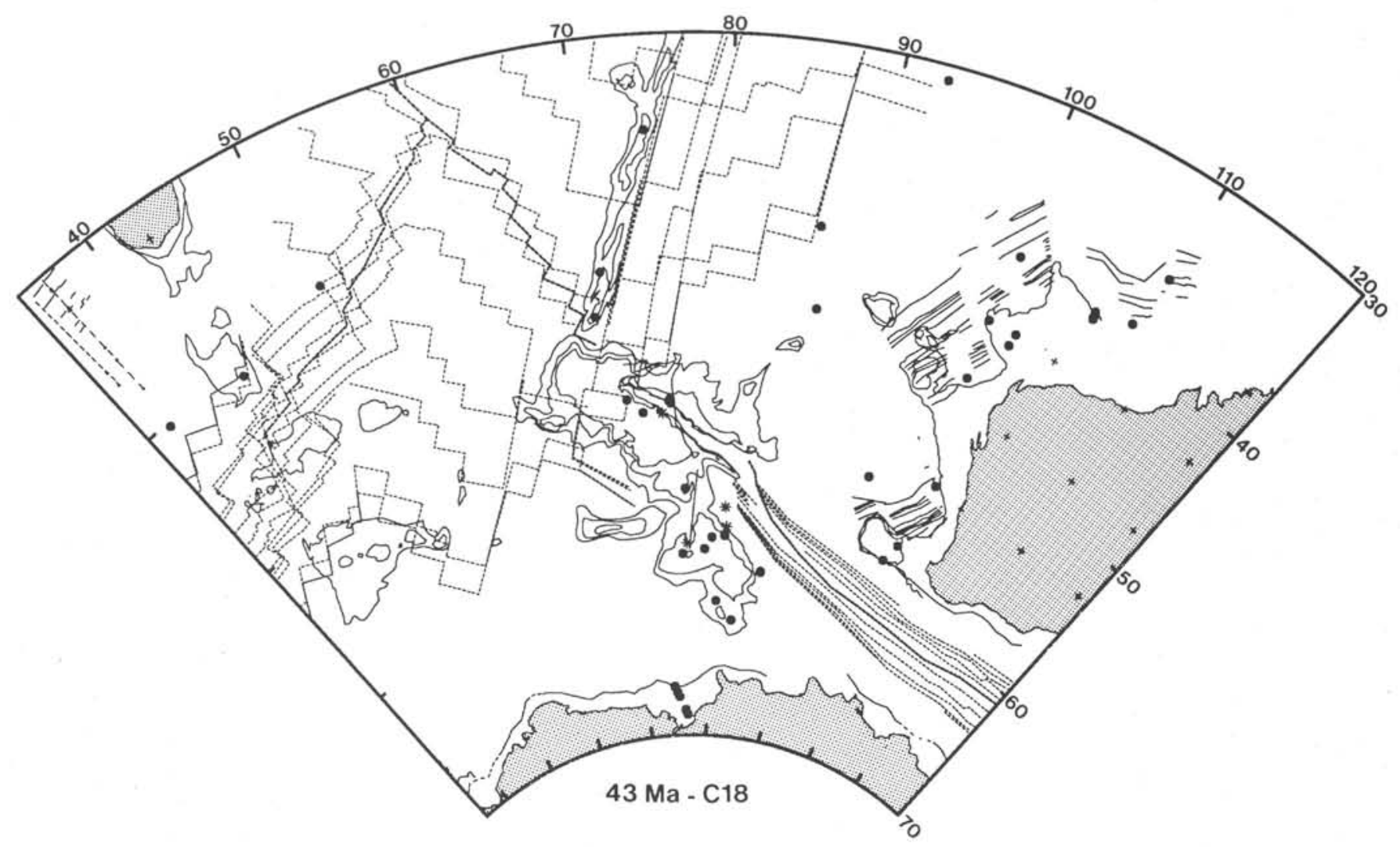

Figure 10. Plate tectonic reconstruction at $43 \mathrm{Ma}(\mathrm{C} 18)$. Transform motion ends between the northern and southern sectors of the Kerguelen Plateau, as the Kerguelen Plateau and Broken Ridge begin to separate. Seafloor spreading between Australia and Antarctica has accelerated to a rate of $22 \mathrm{~mm} / \mathrm{yr}$. Seafloor spreading in the Wharton Basin, between India and Australia, has ceased. Seafloor spreading in the southern Indian Ocean is organized in a pattern that persists through Holocene time. Reconstruction after Royer and Sandwell (1989) and Royer et al. (1988). 